\title{
ECONOMIC UNDERDEVELOPMENT AND THE POPULATION EXPLOSION: IMPLICATIONS FOR U.S. IMMIGRATION POLICY*
}

\author{
RICHARD R. HOFSTETTER $†$
}

I.

\section{INTRODUCTION}

Although the age of European migration has passed, America remains a magnet for the world's immigrants. Today, the United States receives more immigrants than at any previous time in its history ${ }^{1}$ and certainly far more than any other country in the world. These immigrants no longer arrive primarily from Europe, but from Latin America, Asia, and the Caribbean. ${ }^{2}$ Their numbers have increased dramatically in recent years. ${ }^{3}$

It is tempting to equate today's immigration with the earlier period of European migration. Individual immigrants arrive for many of the same reasons as did the Europeans, and the rhetoric of contemporary immigration debate is much the same as in the early part of this century. The prominent symbol is still the Statue of Liberty, which has always represented the open door for immigrants. It is difficult, if not un-American, to regard Emma Lazarus' inscription as anything less than the codification of U.S. immigration policy.

The new immigration, however, is really a contemporary phenomenon: the consequence of rapid and sustained demographic growth in economically underdeveloped regions-a problem which did not exist during the life of Emma Lazarus. Demographic growth is maintained by high birth rates, which are both a cause and an effect of economic underdevelopment. ${ }^{4}$ Underdevelopment, in turn, is the primary reason people seek to migrate. The result is an increasingly large

Copyright (C) 1983 by Law and Contemporary Problems

* I wish to express my thanks to Cliff Goalstone, Allen C. Kelley, William P. Travis, and Arthur F. Corwin for their assistance in the preparation of this manuscript. Their ideas are often presented as my own in the paper, and with these gentlemen I must share recognition. I am also sincerely grateful for the assistance of my wife Nancy, whose editorial skill surpasses mine, and whose knowledge of English grammar has saved me from embarrassment on many occasions. To her this article is dedicated.

$\dagger$ Attorney, Robins, Zelle, Larson \& Kaplan, Minneapolis, Minnesota.

1. Bureau of the Census, U.S. Dep't Of Commerce, Statistical Abstract Of The U.S.: 1980, at 91 , Table 131 (1980) (figures do not include illegal immigrants).

2. Id. at 93 , Table 134 .

3. Id.

4. This proposition is generally accepted by economists, and is assumed for purposes of this paper. Julian L. Simon of Southern Illinois University has taken a contrary position, arguing that high birth rates do not necessarily adversely affect economic development. J. SIMON, THE ECONOMICS OF POPULATION GrowTH (1977). 
pool of would-be immigrants-a situation which will persist until economic development occurs.

Underdevelopment inspires the migration of both labor and capital. Portions of each seek to move from areas of relative surplus to areas of relative shortage. Thus, the Mexican or Haitian comes to the United States looking for work, attracted by the higher wage offered here. This higher wage reflects a relative labor scarcity. Conversely, an American manufacturing firm may depart for Mexico or Haiti, where the higher rate of return on invested capital is a manifestation of relative capital scarcity.

It is the author's thesis that U.S. "immigration policy" should focus on the problem of economic underdevelopment instead of exclusively considering the movement of people. This paper compares the costs and benefits of labor and capital mobility, and concludes that this country's interests are better served by the latter. America's immigration policy should thus foster the mobility of capital while restricting the mobility of labor. Capital investment in those countries sending large numbers of immigrants to our borders may be greatly accelerated by reducing the "opportunity cost" of such investment. At the same time, more restrictions should be placed on immigration to guard the open door.

\section{II.}

\section{The Demographic Background}

Demographers calculate that world population will increase by as much as $2,700,000,000$, or $64 \%$, in the quarter century preceding the year $2000 .^{5}$ Nearly all of this increase will occur in the less developed, or Third World, countries. ${ }^{6}$ The increase attributable to the Third World in the last quarter of this century will exceed the total population of the globe at the beginning of this century. ${ }^{7}$ Never has mankind witnessed such staggering growth in its numbers.

In the 18th century, Thomas Malthus recognized that populations increase geometrically; ${ }^{8}$ two becomes four, four becomes eight, eight becomes sixteen, and so forth, until checked by outside factors. Malthus reasoned that man's ability to increase his own numbers greatly exceeds his ability to increase his means of subsistence, since food production increases only arithmetically (one, two, three, and so on). The necessary consequence of these different growth rates is that population growth will be checked when it exhausts the means of subsistence. This check might sometimes manifest itself as famine. More frequently, though, population growth has actually been restricted in more subtle ways which were related to the

5. Bureau of the Census, U.S. Dep't of Commerce, Current Population Reports: Special Studies SER. P23/79, Illustrative Projections of World Populations to the 21st Century 2 (1979) (high series projection).

6. Id. The population of less developed regions will increase four times as rapidly as that of the more developed nations.

7. Information Please Almanac, 1978, at 106 (1977).

8. T. Malthus, First Essay on Population (J. Bonar ed. 1966). Consider a simple illustration of the power of geometric increase: On January 1, you deposit one penny into a high-yielding account which doubles your investment every day. On January 31 you will have nearly $\$ 11$ million in your account. 
scarcity of food. 9 Whatever the precise nature of the check, Malthus was quite correct in surmising that population growth is always a temporary phenomenon; it cannot be sustained indefinitely. ${ }^{10}$

Malthus assumed that population will always increase to the limit of subsistence, so that population always grows when subsistence is plentiful and stabilizes only when subsistence becomes scarce. Pre-industrial England could not have given Malthus reasonable grounds for believing otherwise. Fortunately, such a dismal forecast has since proven to be at least partially inaccurate. Today's industrialized societies are demographically stable, yet hardly undernourished. Population growth has been checked, but not by subsistence.

Malthus did not anticipate the rise of an important human check. Man, unlike other animals, can voluntarily control the growth of his own numbers. He can do so through increased death rates, decreased birth rates, or some combination of the two. Increasing the death rate is nothing new; war is no stranger to man's history. Lowering the birth rate, however, is a recent phenomenon (and an unquestionable improvement over the former method). Nearly all developed societies have checked population growth by voluntarily limiting births. ${ }^{1}$ (As seen in figure 4, one economically underdeveloped country, the People's Republic of China, has reduced its birth rate. This, however, has been done at the behest of its government. ${ }^{12}$ )

The voluntary reduction in birth rate accompanying modern economic development is illustrated by the "Demographic Transition Model" in figure 1, and supplements (some would say replaces) the Malthusian scheme. Three phases of economic development are shown: pre-industrial, industrializing, and industrialized.

Pre-industrial societies were characterized by high birth and death rates and overall demographic stability. ${ }^{13}$ Death rates were high because pre-industrial societies lacked such modern amenities as proper sanitation, smallpox vaccinations, synthetic insulin, high-yield grains, vitamins, and electric pacemakers. Birth rates in excess of forty live births per thousand per year were necessary throughout most of human history simply to maintain the population. Except for an occasional war, no human check was operative. Malthus' thesis applied: population was limited only by the available subsistence.

9. Pre-industrial peoples seldom starved; the greatest killer was disease. Mortality (particularly infant mortality) was highest, however, when nutrition was poor because susceptibility to disease was greater. Age at marriage was generally higher when nutrition was poor, so that a series of bad harvests would check population growth by increasing deaths and decreasing births without a single death from starvation. See generally W. BorRIE; GROWTH and CONTROL OF WORLd POPUlation (1970).

10. Of critical importance is the point at which population growth will be arrested. Obviously, if population is allowed to expand to the limit of subsistence, consumption patterns characteristic of developed countries cannot be maintained.

11. WORld Bank, WORLd DeVklopment Report 1980, at 144-45, Table 18 (1980).

12. For a brief history of the development of Chinese birth control policy, see C. SUNGLIN, POPULAtion and Population Policy in Mainland China 13-24 (1977).

13. W. BORRIE, supro note 9 . 


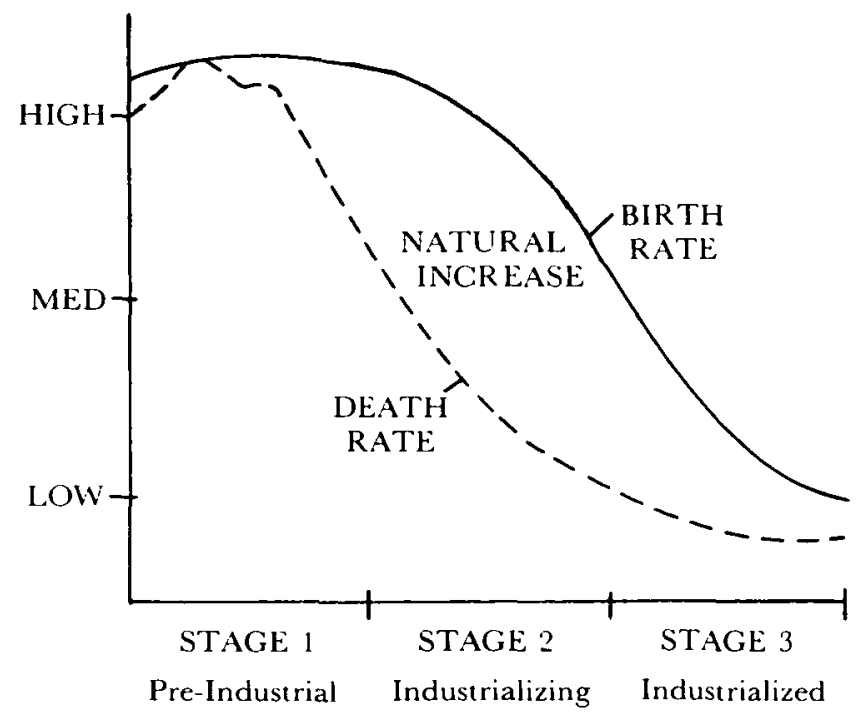

FIGURE 1

THE DEMOGRAPHIC TRANSITION MODEL

Industrialized societies are also demographically stable, but are characterized by low birth and death rates. Death rates below twelve per thousand per year are common among developed societies. ${ }^{14}$ Obviously, birth rates need not be as high as they were in pre-industrial times to maintain population size. Whether people in industrialized countries reduce births in recognition of this fact, or because children are prohibitively time-intensive, or because children compete with other consumer durables, is not clear. Regardless of motivation, the human check stabilizes population at a level which enables developed societies to preserve a high standard of living.

Societies which are in the process of modernizing or industrializing are characterized by low "industrial" death rates, high "pre-industrial" birth rates, and, consequently, rapid population growth. Medical skills and information on nutrition and sanitation are easily transferred and eagerly embraced. Transfer of such knowledge raises the level of subsistence. Unfortunately, attitudes affecting birth rate and family size are not so easily changed. While social values or customs change, the population grows rapidly, and-possibly-the country develops.

Except for a few remote tribes that might remain hidden in South America or Africa, no first-stage, pre-industrial societies exist today. Europe, North America, Australia, New Zealand, and Japan are examples of third-stage, industrialized societies. These areas have experienced transitional demographic growth, but now enjoy stable populations because of voluntary reduction in the number of births.

14. Bureau of the Census, U.S. Dep't of Commerce, World Population 1979-Recent Demographic Estimates for Countries and Regions of the WORld (1980). 
The rest of the world is in stage two, the transitional period of rapid population growth. ${ }^{15}$

Demographic transition is closely related to past and present migrations. Most of Europe passed through the transitional stage during the 19th century, which was, not coincidentally, the golden age of European migration. Europe could not have sent some $51,000,000^{16}$ immigrants to the Americas, Australia, South Africa, and elsewhere had European population not been increasing. Today's immigrants also arrive from transition-stage countries. ${ }^{17}$ It is demographic growth which sustains such migrations.

The word "transition" in this context is a misnomer. It conjures up an image of countries resolutely marching from stages one to three with mechanical precision. This is far from what actually happens, however. Experience has shown that once a society becomes developed, people voluntarily limit births and, hence, the population stabilizes. ${ }^{18}$ Development is, unfortunately, an elusive goal. Some transition-stage countries are already dangerously overpopulated. For them, development may be too distant, or the population crisis too imminent to forestall a Malthusian catastrophe. The critical question for policymakers is not whether population growth will be checked, but whether it will be limited by human effort or by the scarcity of subsistence.

Statistics indicate that the crude birth rate is inversely related to the stage of economic development. ${ }^{19}$ The poorest of the industrializing nations have higher birth rates, and frequently higher demographic growth rates, than the more affluent of the industrializing nations. This strongly suggests that birth rate is responsive to economic factors. ${ }^{20}$ In other words, the shift toward lower fertility is a function of development, ${ }^{21}$ not of time. If a voluntary reduction in the birth rate

15. Id.

16. W. BORRIE, supra note 9 , at 89 . (The figure includes years 1846-1939.)

17. See supra note 3 and accompanying text.

18. See WORLD BANK, supra note 11 , at $144-45$, Table 18.

19. Id.

20. Fertility is affected by economic incentives which operate to encourage fertility wherever there is underdevelopment and discourage fertility wherever there is development. Demographers are reluctant to enumerate these incentives, but it is probable that such factors as the high cost of rearing children, higher rate of literacy and educational level, later age of marriage, lower infant mortality, the desire of women to enter and remain in the labor force, and the high "opportunity cost" of mothers' time, combine to discourage fertility in developed countries. W. BORRIE, supra note 9, at 150-51.

Despite the absence of economic incentives, there is a slight downward trend in world fertility, even in the poorest regions. WORLD BANK, supra note 11 , at $144-45$, Table 18 . This trend may be the result of lower infant mortality. Parents may now have the desired number of children with fewer births, since a higher percentage of children live to adulthood than ever before. Unfortunately, families in less developed countries have very different ideas regarding the desirable number of children than those in developed countries. The main effect of development is to decrease the desired number of children. 1 UNITED Nations, World Population Trends and Policies: 1979 Monitoring Report $50-62$ (1980).

21. "Development" is a complex term and an elusive goal. Real development involves more than increasing the size of the economic pie; it also means slicing it more equitably. Economic growth without development has occurred in many areas, particularly in Latin America, where a prosperous "modern sector" coexists with an underdeveloped sector. In Brazil, for example, $20 \%$ of the population enjoys twothirds of the national income. WORLD BANK, BRAZIL: INTEGRATED DEVELOPMENT OF THE NORTHWEST FrontIER 1 (1981). Per capita income figures for such countries are very misleading, since such data do not reflect such regional economic differences. To suggest that Brazil is "close" to development on the basis of its per capita income figure is incorrect; this would be true only if wealth were more equitably 
only accompanies development, the situation facing many underdeveloped nations is very serious. ${ }^{22}$

Today's population explosion and its resulting pressures toward migration differ significantly from the 19th century European movement. These differences account for a spectacular rise in the rate of population growth over the last century, ${ }^{23}$ which in turn makes prospects for developing (and ultimately controlling this growth) less bright.

First, the manner of acquiring advanced scientific knowledge has changed radically. Europeans developed their knowledge of medicine, sanitation, and diet gradually, so that the death rate was only gradually reduced. This knowledge has been disseminated almost overnight to today's Third World countries, contributing to a precipitous drop in death rates. ${ }^{24}$ Whereas Europe's lowered death rate was a result of technological improvement and economic development, today's transition countries have lowered their death rates prior to noticeable development. In other words, they have entered the transition stage prematurely.

Second, far more countries are currently in transition than ever before. Today's underdeveloped countries account for $75 \%$ of the world's population. ${ }^{25}$ Thus, the majority of the world's population can be expected to increase at a rapid pace unless a major change of direction occurs.

Third, even a dramatic drop in births cannot lead to a stabilized population for some time. Years of population growth in less developed countries have significantly altered the age structure of these populations, so that frequently more than half the population is under the age of twenty. The population pyramids of the United States and Mexico in figures 2 and 3 illustrate the significant difference in age distribution between developed and developing countries. The number of Mexicans reaching the age of fertility compounds the effect of an already high birth rate. Even if the Mexican birth rate were forcibly and immediately reduced to American levels, the Mexican population would continue to grow for some time.

Finally, population is growing more rapidly than before, and the easy solution of the 19th century-massive out-migration-is no longer available. When Europe entered the growth stage, there were still relatively uninhabited continents to which Europeans could migrate. With greater numbers and more advanced technology, the Europeans could-and did-subdue any pre-industrial peoples who stood in their way. Today there are few uninhabited or underinhabited

distributed. It is more accurate to say that part of Brazil is already developed, while part of it is still underdeveloped, and that demographic growth will continue in the underdeveloped sector until it develops as well. For the sake of simplicity and brevity, there will be no further references in this paper to the distinction between economic growth and economic development.

22. Some developing nations-for instance, Taiwan, Singapore, and South Korea-are quite advanced and should reach demographic stability via industrialization without much difficulty. Other nations-particularly those in black Africa-are so primitive that the prospect of industrializing prior to demographic collapse is exceedingly dim. See infra Figure 4.

23. Today's growth rate is much higher than that of Europe, North America, and Japan in their transition. W. BORRIE, supra note 9, at 12-13.

24. Id.

25. Bureau of the Census, supra note 14, Table 1 


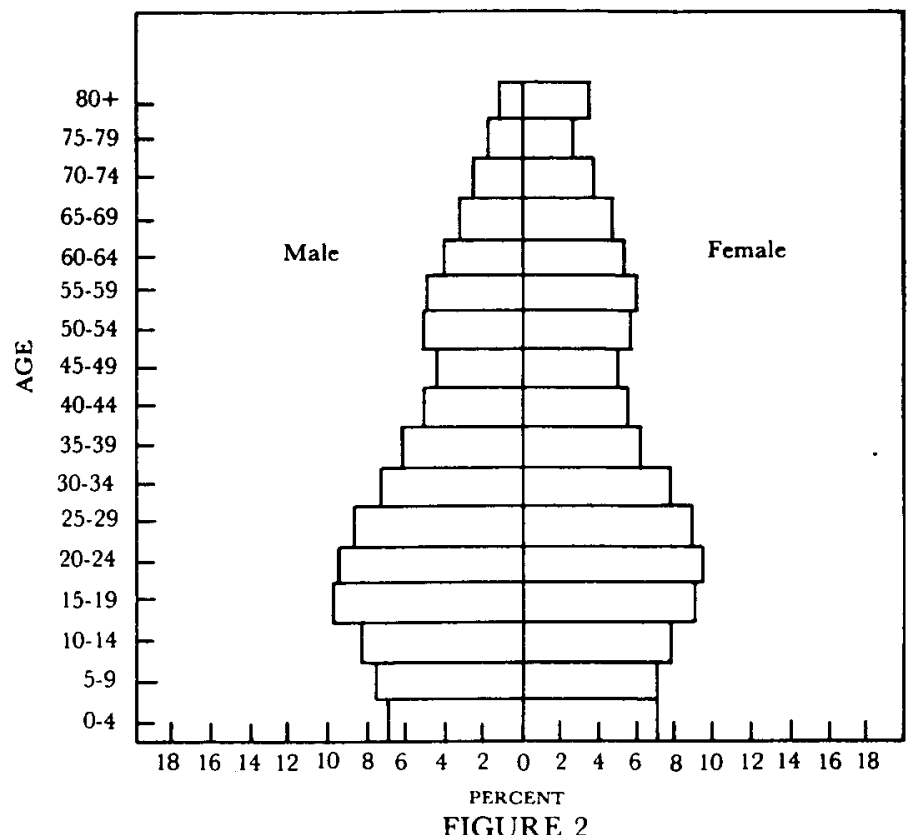

POPULATION PYRAMID OF THE UNITED STATES: 1980

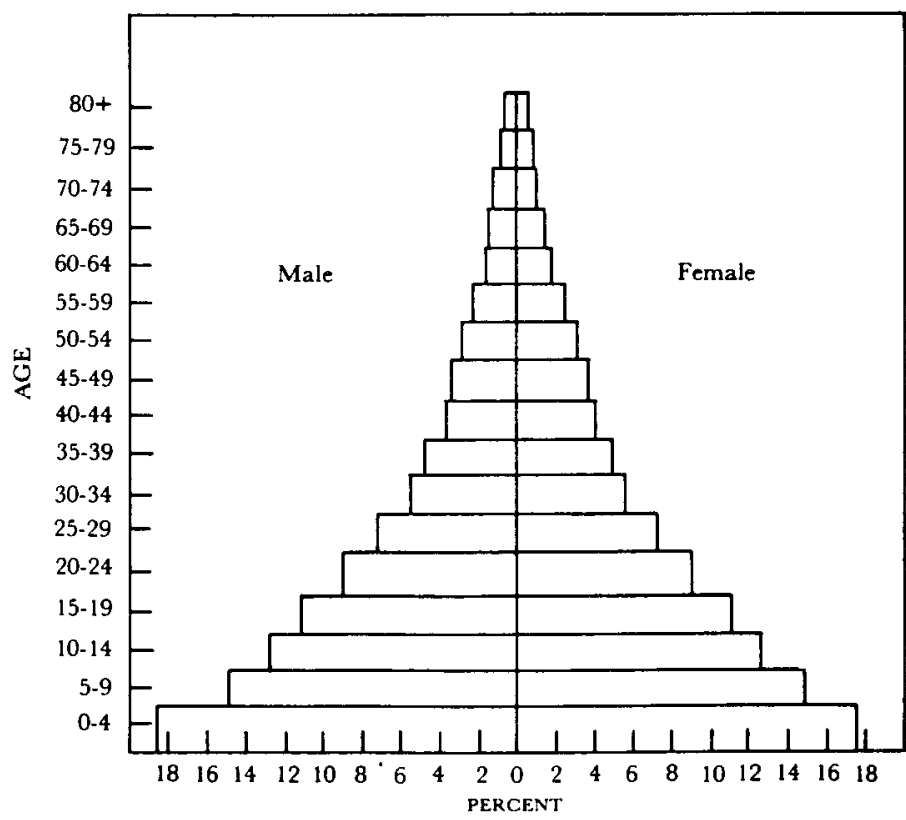

FIGURE 3

POPULATION PYRAMID OF MEXICO: 1980

Source: UN Department of International Economic and Social. AfFairs Selected Demographic Indicators by COUNTRy, 1950-2000: Demographic Estimates and ProJECTIONS AS ASSESSED IN 1978 (1980). 
U.S. IMmigration POLICY

[Vol. 45: No. 2

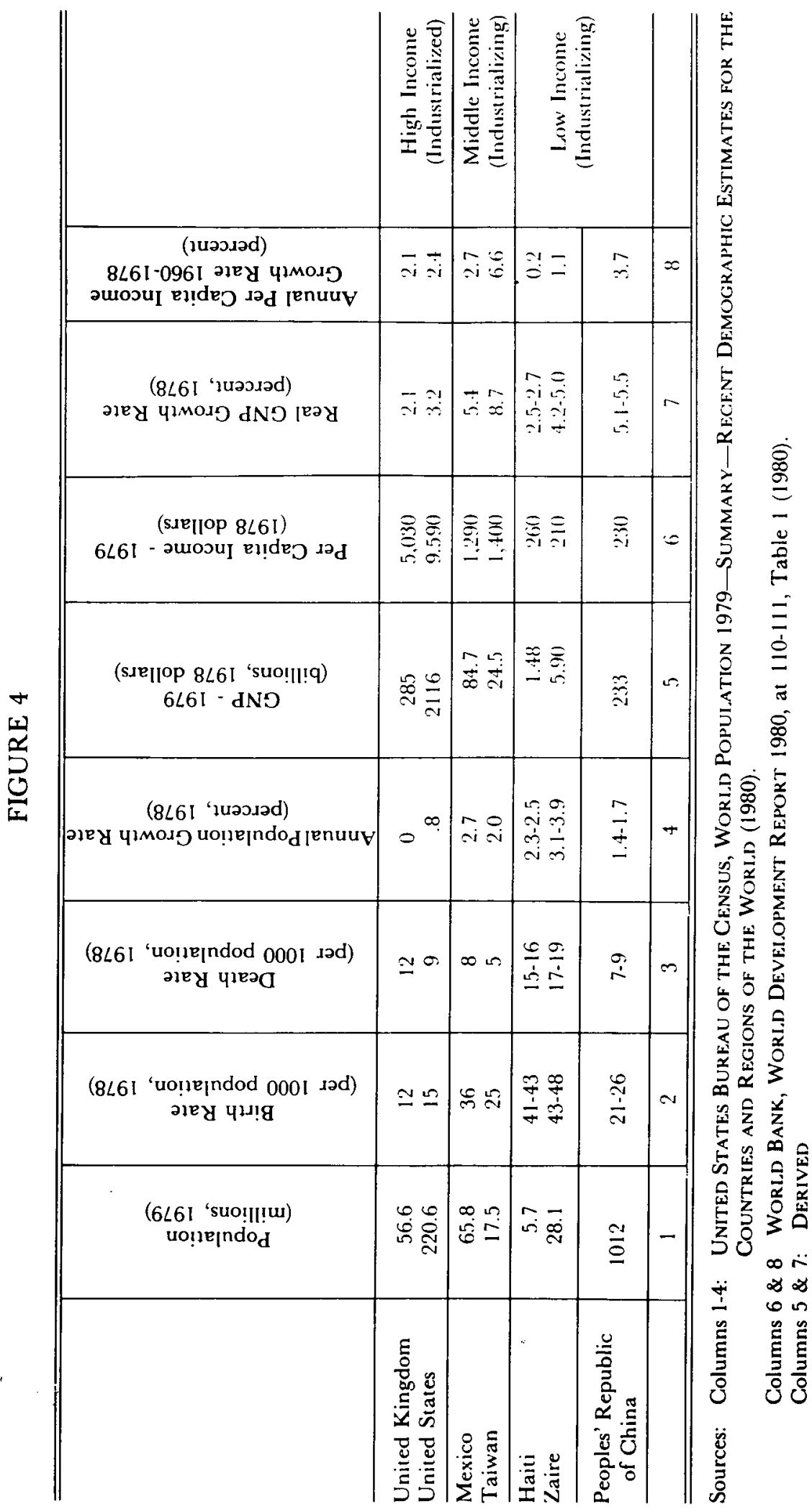


regions with a liveable environment. The only areas which do not have naturally growing populations are those of already developed nations which have the governmental and/or military resources to exclude unwanted immigrants.

Moreover, developing countries may become trapped in a vicious circle, since excessive population growth itself adversely affects economic development. ${ }^{26}$ Per capita income, which is generally indicative of a country's level of economic development, ${ }^{27}$ does not improve if a $2 \%$ rise in gross national product (GNP) is absorbed by a $2 \%$ increase in population. Children enter the world as consumers, not producers, and do not contribute to the work force for some time. A lowering of the birth rate thus has no immediate adverse effect on GNP or productivity, but does contribute immediately to an improvement in per capita income and the ability to save. It is no wonder that the vast majority of developing countries have embraced family planning in principle. ${ }^{28}$

The 20th century economic and demographic picture is of paramount concern to American policymakers. As long as some countries remain economically underdeveloped, their populations will grow and retain a strong economic incentive ${ }^{29}$ to migrate to developed countries. The sheer magnitude of the growth-some $2,700,000,000$ in this quarter-century alone ${ }^{30}$ - vastly exceeds the absorptive capacity of all developed countries. As subsistence becomes increasingly scarce in some of the poorest developing countries, the pressure to migrate will become critical. It is therefore manifestly in the best interest of all nations for the entire world to be developed and prosperous.

The case of Mexico is of particular interest to the United States since it is both a close neighbor and presently the largest source of immigrants. ${ }^{31}$ As shown in figure 4, Mexico currently has a per capita income of $\$ 1,290,{ }^{32}$ which makes it one of the more promising of the transition-stage countries. This is not far behind Portugal, which has a per capita income of $\$ 1,990^{33}$ and a reasonably stable population. ${ }^{34}$ Since Mexican per capita income has been growing at an average annual rate of $2.7 \%^{35}$ for the last two decades, it would appear that Mexico, particularly with its petroleum reserves, should soon be characterized as "developed." The country's demographic position, however, is still very troubled. In 1900, Mexico had a population of only $13,600,000 .{ }^{36}$ Today, its population is $70,000,000,{ }^{37}$ with

26. See supre note 4. While Allen C. Kelley of Duke University agrees that high fertility adversely affects economic development, he has discovered that there is no discernable relationship between population growth and growth in per capita income. Kelley hypothesizes that the relationship between population growth and development is more complicated than previously imagined. Interview with Allen $\mathrm{C}$. Kelley, James B. Duke Professor of Economics, Duke University (Spring 1982).

27. See supra note 21 for an exception to this proposition.

28. The UN's support of family planning reflects the view of these developing countries. See THE UNITEd Nations and POPUlation: MajOR Resolutions and Instruments (1974) for a sampling of UN resolutions and declarations on family planning.

29. See infro text accompanying notes $43-52$.

30. See supra note 5 and accompanying text.

31. Bureau of THE Census, supra note 5, at 93.

32. 1978 dollars. WORLD BANK, supra note 11 , at 111 , Table 1.

33. Id.

34. WORLD BANK, supra note 11 , at 142-43.

35. Id.

36. M. Bonine, C. Gill, R. Holz, J. Weiler, \& S. Arbingast, Atlas of Mexico 24 (1979). 
projections of $116,000,000$ by the year $2000 .{ }^{38}$ This growth represents an eight-fold increase during this century alone; it is obvious that many more Mexicans will be born before the country reaches demographic stability by means of industrialization.

The most amazing fact about Mexican economic growth is that it has managed to make substantial headway against this massive population increase, notwithstanding the economic drain caused by high fertility rates. The Mexican economic growth rate has consistently outpaced the American growth rate, so that Mexican per capita income has actually improved both absolutely and as a ratio to American per capita income. ${ }^{39}$ If Mexico had curtailed its birth rate, it might have been a developed country by now. Had that been the case, Mexico would not be sending immigrants (both legal and undocumented) to the United States at the current estimated rate of some half-million plus per year. ${ }^{40}$ Mexico would cease to be a donor of surplus population for the same reasons that Europe ceased to be a donor.

It is axiomatic that the United States cannot serve as a demographic escape valve for transition-stage countries. The sheer numbers of immigrants already exceed the absorptive capacity of this country. We cannot wait for development to stem the tide of immigration. At least for the present, the law according to Emma Lazarus must be revised and the open door must be guarded. Guarding the door does not, of course, entail excluding all immigrants. It may be to our economic and social advantage to accept limited numbers. The desirable figures must be established in light of potential social costs, demand for services, probable effect on domestic wages, and the rate of domestic unemployment. Given the unacceptably high rate of unemployment, ${ }^{41}$ particularly among minority youths (the category into which most immigrants fall), common sense indicates that the desired level of

37. WORLD BANK, supra note 11 , at 143.

38. Id.

39. Mexican economic growth has been nothing short of extraordinary, notwithstanding recent difficulties which have led to the devaluation of the peso and the nationalization of the banking industry. Consider the table below:

Trends and Projections of United States and Mexican Output and Population $1950-2000$

\begin{tabular}{|c|c|c|c|c|c|c|c|}
\hline \multirow[t]{2}{*}{ Year } & \multicolumn{2}{|c|}{$\begin{array}{l}\text { Gross National } \\
\text { Product (Million } \\
1977 \text { dollars) }\end{array}$} & \multicolumn{2}{|c|}{$\begin{array}{l}\text { Population } \\
\text { (million) }\end{array}$} & \multicolumn{2}{|c|}{$\begin{array}{l}\text { GMP per Capita } \\
\text { (1977 dollars) }\end{array}$} & \multirow[t]{2}{*}{$\begin{array}{l}\text { Ratio of } \\
\text { GMP Per } \\
\text { Capita }\end{array}$} \\
\hline & U.S. & Mexico & U.S. & Mexico & U.S. & Mexico & \\
\hline $\begin{array}{l}1950 \text { (observed) } \\
1960 \text { (observed) } \\
1970 \text { (observed) } \\
1977 \text { (observed) }\end{array}$ & $\begin{array}{r}756 \\
1043 \\
1522 \\
1887\end{array}$ & $\begin{array}{l}15 \\
27 \\
54 \\
74\end{array}$ & $\begin{array}{l}152 \\
181 \\
203 \\
217\end{array}$ & $\begin{array}{l}26 \\
35 \\
49 \\
63\end{array}$ & $\begin{array}{l}4984 \\
5776 \\
7430 \\
8701\end{array}$ & $\begin{array}{r}586 \\
780 \\
1095 \\
1180\end{array}$ & $\begin{array}{l}8.5 \\
7.4 \\
6.5 \\
7.4\end{array}$ \\
\hline $\begin{array}{l}1985 \text { (projected) } \\
1990 \text { (projected) } \\
2000 \text { (projected) }\end{array}$ & $\begin{array}{l}2399 \\
2787 \\
3762\end{array}$ & $\begin{array}{l}120 \\
161 \\
294\end{array}$ & $\begin{array}{l}235 \\
247 \\
273\end{array}$ & $\begin{array}{r}79 \\
89 \\
109\end{array}$ & $\begin{array}{l}10209 \\
11283 \\
13780\end{array}$ & $\begin{array}{l}1519 \\
1809 \\
2691\end{array}$ & $\begin{array}{l}6.7 \\
6.2 \\
5.1\end{array}$ \\
\hline
\end{tabular}

Source: Immigration and Nationality Effriency Act of 1979: Hearings on S. 1763 Before the Senate Comm. on the Judiciany, 96th Cong., 1st Sess. 224 (1979) (Reynolds, U.S. Labor Market Projections and Their Relevance to Current Migration Controversies).

40. See Bureau of The Census, supra note 1, at 93

41. In September 1982, nationwide unemployment stood at 10.1\%, the highest level since 1940. Black unemployment exceeded 20\%. Beating Gloom to the Punch, TiME, Oct. 18, 1982, at 22. 
immigration is well below the current level. ${ }^{42}$

\section{III.}

\section{LABOR IMPORT Versus Capital ExpOrt: Houston OR Saltillo?}

The capital-to-labor ratio can be considered indicative of a country's stage of economic development. Less developed countries tend to have a relative surplus of labor and insufficiency of capital, while developed countries tend to have a relative surplus of capital and insufficiency of labor. ${ }^{43}$ Where there is a labor surplus, wages tend to be low; where there is a labor shortage, wages tend to be high. Workers in developed countries are thus better paid than workers in underdeveloped countries.

When capital and labor are mobile, each moves from areas of relative surplus to areas of relative shortage, and thereby earns a higher rate of return. Workers migrate from areas in which the prevailing wage rates are low to areas in which the prevailing wage rates are high, and investors similarly attempt to maximize the rate of return on capital by seeking areas of relative capital shortage (which most often are areas of relative labor surplus). With perfect mobility the process continues until labor and capital earn comparable returns in all areas-that is, when wage and profit differentials are eliminated.

Viewed from this perspective, today's immigrants are wage equalizers. The Mexican who makes his one-way passage to Houston does so because he is seeking work at American wage rates. If enough Mexicans follow, the presence of many Mexicans seeking work will depress wages in Houston. This effect is a matter of great consternation to the American labor movement, which has consistently opposed open-door immigration.

The economic equivalent of immigration is American investment in Third World countries. A labor-intensive business-for example, a Houston widget manufacturer-may discover that it can no longer profitably compete with cheaper widgets from Taiwan because American wage rates are prohibitively high. Faced with the choice of terminating his business, filing a petition for trade relief, ${ }^{44}$ or seeking cheaper labor, the company president may elect to move his factory to Saltillo, Mexico.

This tendency toward the equalization of wage rates and return on capital exists only when labor and/or capital are mobile. Immigration laws may restrict the mobility of labor, while tariffs, import quotas, taxes, transportation costs, and

42. Further speculation as to the desirable number of immigrants involves policy considerations which are beyond the scope of this paper.

43. It is undeniably true that a small number of underdeveloped countries are experiencing labor shortages. Saudi Arabia, in particular, must import large numbers of workers from both developed and underdeveloped countries. Central Dep't of Statistics, Ministry of Finance and Nat'l Economy of the Kingdom of Saudi Arabia, Employment and Wage levels in Privately OWned EstabLISHMENTS (1978). This proposition, however, is generally applicable to the Third World, especially to those countries which are exporting large numbers of immigrants to the United States.

44. A petition may be filed with the Trade Representative requesting the President to enforce trade agreements or respond to practices which "unjustifiably restrict U.S. commerce." Trade Agreements Act of $1979 \S 302,19$ U.S.C. $\$ 2412$ (Supp. IV 1980). The International Trade Commission may be petitioned for relief in adjusting to import competition. Trade Act of $1974 \S 201,19$ U.S.C. $\$ 2251$ (1976). 
perceived risks of foreign investment may restrict the mobility of capital. The Mexican is mobile because the Immigration and Naturalization Service, being perennially underfunded and notoriously ineffectual, cannot easily exclude him; the widget manufacturer is mobile as long as the added costs of doing business in Saltillo do not prevent him from obtaining a higher rate of return there.

When Mexicans depart for Houston, Mexico is better off economically (assuming the migrants do not depart with significant amounts of capital). Mexico's unemployment rate decreases slightly, resulting in an upward pressure on wage rates. Per capita income increases because national wealth is divided among fewer Mexicans, and emigrant Mexicans frequently repatriate a portion of their U.S. wages. ${ }^{45}$ (Small wonder the government endorses their departure!) When the Mexicans arrive in Houston, they add to the American work force. The rate of unemployment increases, resulting in a downward pressure on wage rates. Per capita income declines, since the same national wealth is now shared by more people (which is one reason the U.S. government and U.S. labor unions would like to exclude Mexicans). Suppose, however, that these immigrants find jobs in a Houston widget factory. The factory may fire Americans because the Mexicans are willing to work for far less. (The widget manufacturer is frequently able to evade both compliance with the U.S. minimum wage rate and labor resistance.) The company will be more profitable as a result of paying lower wages to Mexican workers, and a portion of these profits may be passed on to the consumer in the form of lower prices. There are thus economic benefits as well as detriments to the American economy.

The departure of an American widget factory for Saltillo would have similar economic consequences for both countries. When the factory concludes its operations in the United States, Americans will be out of work. Unemployment will rise, wages will be weakened, and per capita income will decline. When the factory reopens in Saltillo, unemployment in Mexico will decline, there will be an upward pressure on wage rates, and per capita income will increase. Since the Mexican workers will receive lower wages than their American counterparts, the widget manufacturer's profits will rise. The widgets which ultimately grace $\mathrm{K}$ Mart shelves in Houston may be lower priced, thus benefiting the American consumer. Again, there are economic benefits as well as detriments. On the surface, at least, it appears that the economic effects of immigration and foreign investment are perfectly symmetrical.

Economists are prone to simplify human lives, however, in order to pursue their economic analyses. Both capital and labor movements entail "social costs," costs which economists avoid because they are difficult to quantify and therefore do not fit neatly into economic analysis. When Mexicans migrate to Houston, for example, the United States bears substantial social as well as economic costs. The new arrivals are generally poor and nonwhite, have little formal schooling, and do not speak English. They typically join a Mexican urban enclave, where they con-

45. Mexicans repatriate approximately $30 \%$ of their earnings. Gomez-Quinones, Mexican Immigration to the United States and the Intermationalization of Labor, 1848.1980: An Overview, in MEXICAN IMMIGRANT WORKERS IN THE U.S. 16 (A. Rios-Bustamante ed. 1981). 
tinue to speak Spanish and raise Spanish-speaking children. ${ }^{46}$ The arrivals and their descendents thereby become a linguistic and cultural underclass. ${ }^{47}$ Frustrated expectations breed crime, and the cycle of poverty is perpetuated. The social cost of Mexican immigration is substantial, and the problem of quantifying these social costs does not justify ignoring them.

Similarly, the relocation of a widget factory to Mexico entails social as well as economic costs. The presence of the factory in Saltillo makes the city more economically attractive than the rural areas, thus accelerating and perhaps disorganizing the process of urbanization. There may be a stampede of workers to the factory gates, as too many Mexicans apply for too few jobs. If unsuccessful applicants remain in the city, ghettos develop, resulting in familiar urban blight. The factory may emit industrial pollution, and a visible, prosperous foreign owner may foster resentment. Again, these social costs are too substantial to be ignored simply because of difficulty in measuring them.

Can it be said that the social costs of capital and labor migration are roughly symmetrical? On the contrary, upon closer analysis, it becomes clear that the social and economic costs of capital and labor migration are actually asymmetrical and that capital migration is preferable to labor migration.

Consider first the question of economic symmetry. The widget factory which relocates in Saltillo does so because the lower labor cost in Mexico enables the firm to realize a higher rate of return. The company's rate of return in the United States is unacceptably low because it cannot compete successfully with cheaper widgets manufactured in Taiwan and imported into the United States. The Taiwanese manufacturer is successful, notwithstanding any "voluntary" export restraints imposed on Taiwanese manufacturers at the behest of the U.S. government, because Taiwanese labor is cheaper than American labor. Rather than petitioning the International Trade Commission for investigation and relief, ${ }^{48}$ management has chosen to compete more directly with the Taiwanese by employing a Mexican work force. At first glance, it appears that American workers have suffered a substantial injury by forfeiting their jobs.

While management's decision to move may have injured workers, the extent of this injury is mitigated. In a free trade market in a world in which substantial differences exist between the levels of economic development, the widget manufacturer must either move or go out of business. For the foreseeable future, American workers will command higher wages than Taiwanese workers. Hence, the rate of return on the manufacture of widgets in the United States will remain unacceptably low unless the American firm can reduce its labor costs, achieve extraordinary gains in worker productivity, or obtain a public subsidy through trade protection. The factory which departs for Saltillo, then, is no great loss to the United States; it was dying anyway.

In Saltillo, the firm will be rejuvenated, and will once again be a viable,

46. Bronfenbrenner, Hyphenated Americans-Economic Aspects, LAW \& CoNTEMP. Probs., Spring, 1982, at $25-26$.

47. Id.

48. See supra note 44 . 
profitable enterprise. Mexico will have received a real prize. American workers will grumble, but their $\operatorname{loss}^{49}$ (a job likely to have been terminated anyway) is insignificant when compared to Mexico's gain (a badly needed, efficient industry). In an absolute sense, America may still gain: consumers may have the benefit of lower-priced widgets, and the transplanted corporation will probably continue to pay U.S. taxes. ${ }^{50}$ Mexican workers so employed will become consumers in the world market, and U.S. exports to Mexico will consequently increase. The displaced U.S. widget workers may thus find jobs made available in a more efficient export industry. The overall effect of the relocation of the widget factory is synergistic: it can produce greater and more equitably distributed wealth, higher productivity, and improved efficiency.

Compare the above scenario with the arrival in Houston of enough Mexicans to staff a typical widget factory. As discussed earlier, the immigrants will depress American wages, contribute to unemployment, and reduce per capita income in the United States. Clearly, from the perspective of the United States, the departure of the widget factory is preferable to the arrival of the immigrants. Mexico, too, has compelling reasons for preferring capital to labor mobility. ${ }^{51}$ As mentioned earlier, the departure of Mexicans for Houston raises per capita income and lowers unemployment in Mexico-substantially the same economic effects caused by the arrival in Saltillo of an American widget factory. But importing factories is preferable to exporting Mexicans, since the factory is a tangible benefit which directly fosters economic development. The factory adds fixed capital, management expertise, and technical knowledge to the Mexican economy. The factory may grow and diversify, so that economic benefits will compound over time. Adding capital to the economy is more beneficial in the long run than subtracting workers.

Clearly, the economic effects of capital and labor mobility are asymmetrical. Both the United States and Mexico would prefer capital to labor mobility because of the synergistic benefits generated by foreign investment (although Mexico would not eagerly surrender the sums repatriated by its guest workers, and would, under the best of circumstances, like to export workers as well). Capital mobility is also preferable to labor mobility in the context of the earlier discussion of demographic growth, since underdevelopment is the real cause of today's population problem. While labor mobility treats primarily the symptoms, capital mobility strikes at the disease.

The social costs of labor and capital mobility are likewise asymmetrical. The social costs of capital mobility for Mexico are really the growing pains which any developing nation must experience. A certain amount of urbanization, industrial pollution, and complex adminstration is the price of economic development. The

49. The loss is further softened by unemployment compensation.

50. The U.S. corporation will, of course, receive either a direct or indirect tax credit for Mexican income taxes paid. Mexican corporate tax rates are, however, lower than U.S. corporate tax rates; the firm will therefore eventually pay the difference to the U.S. Treasury. See generally PRICE WATER HOUSE, DOING Business in MEXICO 91-111, 184 app. I (1979).

51. Mexico would clearly prefer to both export workers to the United States and import factories from the United States as the most ideal opportunity for improvement. 
social costs faced by Mexico upon the opening of a widget factory are thus necessary ones so long as economic development continues to be a national priority for Mexico. To mitigate the harshness of economic growth, efforts can be made to preserve national identity in customs, dress, and language.

On the other hand, the social costs incurred by the United States when it absorbs Mexican immigrants are quite unnecessary. The United States is already developed; Mexican immigration is not a prerequisite for accomplishing any national priority. The further cost of assimilating an untrained work force into the U.S. economy and culture only inhibits economic growth while increasing social and racial tensions. ${ }^{52}$

Since the social costs incurred through capital mobility must be borne by Mexico at some stage in its economic development, while the costs of labor mobility are unnecessary, there is a compelling reason to prefer the former.

\section{IV.}

\section{CONDITIONS FOR SUCCESSFUl FOREIGN INVESTMENT}

Given the desirability and preferability of capital mobility, two questions are presented: (1) What are the conditions for successful foreign investment in laborsurplus countries? and (2) How can foreign investment in labor-surplus countries be accelerated? This section will address these questions.

Broadly speaking, from the perspective of the relocating firms, there are two fundamental conditions for successful foreign investment. ${ }^{53}$ First, the investing firm must be able to realize a higher rate of return on invested capital in the host country. Second, the relocating business must be permitted to remit these profits to its home country. There are a number of factors which may prevent firms from realizing these objectives, such as unreasonable regulations, high taxes, lack of adequate industrial infrastructure, prohibitive transportation costs, lack of human capital, unavailability of essential industrial inputs, increased risk of loss, and lack of a secure political environment. These factors, which are largely beyond the control of the investing firm, account for the fact that some countries are much more attractive to investors than others. American firms scrambling to invest in Mexico ${ }^{54}$ would not consider, for instance, a similar venture in Iran.

Broadly speaking, from the perspective of the host country, there are also two fundamental conditions for successful foreign investment. First, the investing firm must generate economic benefits which exceed costs, including social costs. Second, the host country must be able to successfully translate the experience into economic "development."

52. William P. Travis of Indiana University proposes a cost-effective halt to immigration by instituting a wage subsidy for American workers. Travis, Migration, Income Distribution, and Welfare under Alternative Intemational Economic Policies, LAW \& CONTEMP. PROBS., Spring 1982, at 105. This interesting proposal should be given close scrutiny.

53. Other criteria have been suggested by the United Nations Commission for Asia and East Asia, discussed in P. Alpert, Economic Development: Orjectives and Methods $236-39$ (1967).

54. Besides being the leading source of immigrants to the United States, Mexico is especially attractive to foreign investors. Mexico offers cheap energy as well as cheap labor, and its well-developed infrastructure, proximity to the United States, and political stability make it an ideal country for our discussion. 
The goals of the investing firm and the host country are different but not necessarily conflicting. Unfortunately, countries and corporations are frequently at odds, so that the pace of foreign investment and national development is slowed. ${ }^{55}$ Many of the factors inhibiting investment are within the power of firms and governments to control. Failure to resolve the unnecessary conflicts between host countries and corporations may be destructive to both, as seen in the experience of the multinational corporations.

In recent years American, Japanese, and European multinationals have successfully relocated a large number of operations in developing countries. This type of foreign investment has generated new profits, notwithstanding the added costs of operating in foreign environments with unfamiliar laws, customs, and languages. But while investment by multinationals has been a business success, it has frequently been viewed as a failure from the perspective of the host countries. ${ }^{56}$ Multinationals are, after all, motivated by profit, and their contributions to development are usually unintended by-products.

For years multinational firms were heavily concentrated in the extractive industries. Such industries tend to be capital-intensive, requiring a relatively high capital investment for each job created. Consequently, these businesses contributed little toward alleviating unemployment problems, while frequently appearing to rob host countries of mineral wealth. ${ }^{57}$ In many places extractive industries appeared during or shortly after the end of colonial rule, ${ }^{58}$ an association which did not enhance the public image of the multinationals. It is hardly surprising that such industries have been a favorite target for nationalization.

More recently, multinationals have come to recognize the wage differential itself to be a natural resource, and for this reason have relocated manufacturing operations abroad. ${ }^{59}$ Such operations employ relatively more of the local work force than do the extractive industries, thereby more directly fostering economic development. These enterprises are not without their problems, however. Typically, the multinational firm attempts to buy passive labor by offering wages substantially in excess of the prevailing rate in the host country. Wages which are too high attract an excess supply of job applicants, contributing to lines at plant gates and urban blight in surrounding neighborhoods. The firm, meanwhile, is happy to pay this premium for local labor, since it probably represents only a sliver of the wage differential that exists between the host country and the multinational's base country. Thus, the corporation absconds with the lion's share of the wage differential; its profits are then decried by nationalists and Third World revolutionaries as excessive and exploitative. Wages are thus simultaneously too high and too low. Executives may justify most of the wage differential on the grounds that it offsets

55. See I. Frank, Foreign Enterprises in Developing Countries 25-29 (1980); K. Grifrin, INTERNATIONAL INEQUality AND National POVERTy 42-46 (1978).

56. L. Solomon, Multinational Corporations and the Emerging World Order 75-106 (1978).

57. Id. at $77-79$.

58. Id. at $75-106$.

59. In recent years this investment has reached billions of dollars. I. Frank, supra note 55, at 10 . 
the risks, inconveniences, and added expenses of operating in unfriendly and misunderstood environments.

An interesting modification of labor-consuming investment is the so-called "inbond," or split factory. Many products involve relatively distinct labor-intensive and capital-intensive manufacturing stages. A number of American firms have relocated only the labor-intensive manufacturing stage to Mexico, ${ }^{60}$ and ship semifinished products between Mexican and American sister factories. In essence, the in-bond factory is really one unified operation which straddles the American-Mexican border. Such operations do relieve unemployment in Mexico, but still suffer from the too high/too low wage contradiction. Since the in-bond factory handles only intermediate products, the potential for growth and diversification is also quite limited.

With the checkered history of foreign investment, it is not surprising that most developing countries seem to prefer direct, unconditional handouts to accelerated foreign investment. ${ }^{61}$ President Reagan rejects the handout philosophy, supporting instead increased participation by the private sector in the development of the Third World. ${ }^{62}$ Such a program is not likely to be warmly embraced by the developing world, however, so long as foreign investment takes its present form.

There is an alternative to investment by the large multinational firm. Ironically, it is not the multinationals which can best profit from cheap labor, but rather the mid-sized, labor-intensive companies which are encountering stiff competition from imports-the Houston widget manufacturer discussed earlier. The host government would prefer the widget manufacturer to the multinational as well; the widget factory is smaller and relatively innocuous. Host governments prefer several, successful smaller companies to one or a few dominant multinational corporations. Where the U.S. firm is battered by imports, relocation provides the opportunity for greater synergistic benefits. ${ }^{63}$

Unfortunately, such labor-intensive firms are frequently unaware of the opportunity presented by foreign investment. Those companies which do recognize the opportunity have been slow to utilize it because they lack the assets or personnel to effectuate the move, perceive the risks of operating in an alien environment as

60. See generally L. Turner, Multinational Companies and The Third World (1973). In 1969 nearly $70 \%$ of Mexico's exports to the United States were composed of American-made parts. Id. at 177.

61. This oversimplifies the demand of the "New International Economic Order" but it does capture the bias. See, e.g., Independent Comm'n ON INTERnational Development Issues, North-SOUTH: A PROGRAM FOR SURVIVAL (1980).

62. In February 1982, the Reagan administration announced a Caribbean Basin Development Plan. One principal goal is to reduce the migration of "economic refugees" from overpopulated Central American and Caribbean countries by providing economic development aid to stimulate economic growth, thus absorbing some of the surplus labor population, as in Haiti or the Dominican Republic. Another purpose is to help stabilize the Caribbean countries politically in order to reduce the out-migration of political refugees and victims of civil war from such countries as Nicaragua, El Salvador, and Guatemala.

The plan calls for a direct foreign aid package of $\$ 350,000,000$ from the United States as well as various tax and tariff reductions to encourage U.S. private and other foreign investment in the Pan Caribbean area. Address Before the Permanent Council of the Organization of American States, 18 WEEkLY CoMP. Pres. DoC. 217.23 (Feb. 24, 1982).

63. See supra pp. 65-69. 
outweighing the benefits, or simply oppose leaving the home base. ${ }^{64}$ Obviously, IBM can establish an operation in Saltillo more easily than a mid-sized widget manufacturer from Houston. IBM risks proportionately far less and is already equipped to manage the foreign operation. The widget manufacturer, on the other hand, risks his entire business, and would have greater difficulty managing the new operation. The "opportunity cost," in other words, is prohibitively high for mid-sized companies.

If the opportunity cost for such mid-sized firms could be reduced, the pace of foreign investment could be greatly accelerated. A large reduction in the opportunity cost of investment could be attained if new, service-oriented international corporations provided comprehensive packages of services. A new international division of labor is needed - a type of market mobilization which is largely lacking today. ${ }^{65}$

Labor-intensive operations require a large labor input in proportion to capital investment. They are also typically low in fixed capital, that is, capital goods which are valuable only for a particular manufacturing operation and no other. A steel mill, which is capital-intensive as well as high in fixed capital, is useful for manufacturing steel and nothing else. A factory which manufactures shoes, on the other hand, is labor-intensive, low in fixed capital, and could be adapted at relatively small expense to house another labor-intensive operation-say, a furniture or widget manufacturer. The "adaptation" could be as simple as changing the equipment inside the factory building.

Herein lies a splendid opportunity to reduce the opportunity cost to mid-sized, labor-intensive businesses. Factory buildings could be designed to serve a number of different labor-intensive operations. These buildings (known as "swing buildings" in construction parlance) would be valuable in and of themselves, regardless of the operation they happen to house at any particular time. Several of these factory buildings could be constructed in developing countries and leased to American labor-intensive businesses, which would install appropriate equipment and begin production. By leasing rather than financing the buildings, the mid-sized firms would be able to relocate with far less capital at risk.

Consider how the plan might be organized. A Mexican firm could construct an industrial park of such multi-purpose factory buildings in Saltillo. The firm might have the financial backing of the Mexican government and the World Bank, which might also be equity holders. Each building could already be supplied with roads, sewers, and utility hook-ups. The firm would manage and service

64. One mechanism already used in facilitating the movement of capital is the export processing zone, whereby a government provides a suitable package of investment incentives to both foreign and domestic entrepreneurs. To encourage this, legislation must be passed giving investors such incentives as fixed-term corporate tax exemption, duty exemption on production machinery imports, and freedom to repatriate profits at a certain rate. Asian Productivity Organization, Export Processing Zones in Asia: SOME DIMENSIONS I (1977).

65. Historically, international industrial parks have suffered many problems. The proposal here is far more comprehensive than the usual scheme. For discussions of contemporary industrial park plans, see UN INDUSTRIAL DEVELOPMENT ORGANIZATION, GUIDElINES FOR THE ESTABLISHMENT OF INDUSTRIAL. Estates in Developing Countries (1978); UN Industrial Development Organization, The EfFectiveness of Industrial Estates in Developing Countries (1978) 
the entire complex, much like a typical landlord, and collect "rent" from each of its "lessees."

Because the managers of the industrial park would be Mexican, they could provide an additional package of services which would be of inestimable value to the American lessees. The American firms would, by and large, be diversifying abroad for the first time. Lack of experience, incomplete knowledge of Spanish, and unfamiliarity with the written and unwritten laws of custom and business spell disaster. The management firm would therefore screen and hire workers, supply utilities, contract with Mexican suppliers for required industrial inputs, and pay all concerned parties on behalf of the lessees. (As a volume purchaser, the management firm may be able to negotiate more favorable rates for the lessees.) Charges for accumulated wages, utilities, and industrial inputs would be presented to each lessee in one convenient, itemized monthly bill. Each lessee would thereby be relieved of the burden of dealing with a large number of Mexican entities. For these services, the management firm would charge a reasonable fee. Since the cost of labor, utilities, and other inputs would be contractually determined in advance, a mid-sized manufacturer would be able to plan with an unprecedented degree of accuracy. The package of services would also enable the factory to be operated by a smaller management team.

This idea can be developed even further. An American firm located in Houston, perhaps a minority equity holder in the Mexican management firm, could locate and screen potential lessees for the industrial park. For a reasonable fee, the American firm would become an obligor to the Mexican management team for labor, utilities, and other inputs consumed by each lessee at the industrial park. Acceptable lessees would lease the building, labor, utilities, and inputs directly from the American firm. Each would pay its itemized monthly rent ${ }^{66}$ directly to the American firm in dollars ${ }^{67}$ and would be entitled to enforce in American courts the provisions of the labor, utility, and input contracts. ${ }^{68}$ The advantages of such an arrangement are obvious.

This hypothetical service and management organization would drastically reduce the opportunity cost of foreign investment and could greatly accelerate the relocation of mid-sized labor-intensive businesses. The managing organization would offer to foreign investors a single contract which in effect would import Mexican labor but not Mexican workers; the contract itself would embody the wage differential. The service package also would reduce costs, which would increase the realizable wage differential, thereby enabling the host organization as well as the relocating manufacturer to be highly profitable. As a result, American

66. Such "rent" would include most or all production expenses.

67. The American firm would absorb the risk of currency devaluation or revaluation. The extent of this risk could be mitigated by astute purchases of pesos and currency futures contracts.

68. Disputes between the lessees and the American firm would be resolved in American courts. Disputes between Mexican suppliers or workers and the Mexican management firm would be resolved in Mexican courts. Disputes between the American firm and the Mexican managers could be resolved by arbitration or in a forum of choice. Thus, if a Mexican supplier breaches a contract which disrupts production in lessee A's factory in Mexico, lessee A would collect from the American firm, the American firm would collect from the Mexican management firm, and the Mexican management firm would collect from the breaching supplier. The order is reversed if, for example, lessee $A$ breaches its rent obligation. 
businesses which otherwise may lack the inclination or wherewithal to move abroad might choose to relocate.

Such an organization would also be an improvement from the host country's perspective. The Mexican management firm may set pay scales at the country's prevailing wage rate to avoid problems associated with excessive wages. At the same time, the Mexican government could be an equity holder in the management firm itself and participate in the profits generated by the organization. Thus, the too high/too low wage contradiction would be largely resolved. In addition, the portion of the wage differential accruing to the government through the profits of the organization could be redistributed to the workers in a more structured fashion (perhaps by improving local infrastructure) which comports with the host country's developmental objectives while minimizing social costs.

\section{V.}

\section{Distribution of the Wage Differential}

This section ${ }^{69}$ analyzes the wage differential as augmented by the provision of low-cost input packages and the way in which the wage differential is divided among the suppliers of services (the service network), the receivers of services (the lessees), and the host governments. Several simplifying assumptions are made.

First, assume that the wage differential is the only net factor-price differential. All other factor-price savings, such as energy, are cancelled out by factor-price increases, such as transportation. This scenario would still encourage a steady flow of foreign investment to low-income countries in which low-cost multi-service packages are available. For example, if wages and benefits of workers in the United States are $\$ 15,000$ per worker per year and only $\$ 3,000$ per worker per year in Mexico, there is a strong incentive for American businesses to employ Mexicans in Mexico. If all workers have equal productivity, the net wage differential is $\$ 12,000$ per worker per year. If labor-intensive American businesses can realize a large part of this net wage differential, their overall costs will be substantially reduced.

Second, assume that all lessees have identical requirements for labor; they face the same wage rates and hire the same number of workers. Third, assume that all of the leased factories are the same size, so that square feet per worker is identical. Fourth, assume that the value added by the service network is equal for all lessees. Thus, the lessees are homogeneous in every respect.

Armed with these assumptions, consider four aspects of the model: constraints, shifting of constraints, equilibrium, and disequilibrium.

In graph 1, the left-hand vertical axis is the number of industrial plants to build and service, and the right-hand verticle axis is the number of industrial plants to lease. The symbols represent the service network's point-of-view origin "O" and a progression through the alphabet. Thus, the service network's point of view is measured from the left, while the lessee corporation's point of view is mea-

69. This section was contributed by Cliff Goalstone of Kobe University, Japan. 
sured from the right. The distance between these axes is the net wage differential plus the value added by the service network.

GRAPH 1

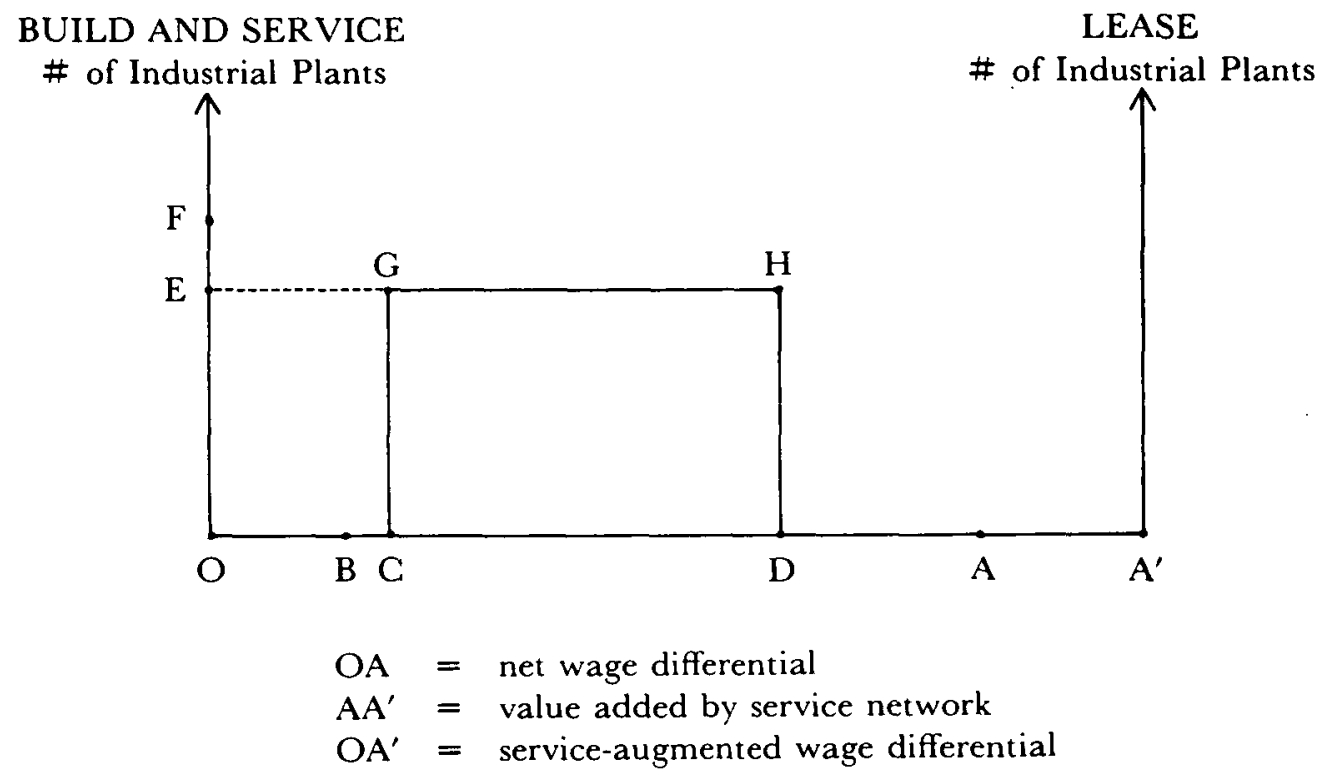

The distance $O A$ is the net wage differential per lessee. Using an annual differential of $\$ 12,000$ per worker times 200 workers per factory, the annual net wage differential is $\$ 2,400,000$ per lessee per year-quite a spectacular cost reduction. The distance $\mathrm{AA}^{\prime}$ is the tangible and intangible value added by the service network per lessee. The overall distance $\mathrm{OA}^{\prime}$ sets the limit on the net benefits to be enjoyed for each factory through the service network. The distance $\mathbf{A A}^{\prime}$ is small relative to $\mathrm{OA}$, indicating that the utilization and distribution of the wage differential is the greatest benefit to foreign investors.

The distance OC represents the costs of doing business in the foreign country. Business taxes imposed by the host country equal $O B$. The minimum level of fees necessary to maintain a no-growth service network is $\mathrm{BC}$. It should be noted that the graph shows that $\mathrm{OC}=\mathrm{AA}^{\prime}$, which indicates that the value added by the services is enough potentially to keep the net wage differential intact.

The distance $A^{\prime} D$, measured from the right, is the minimum level of benefits which the most eager lessee would require before contracting with the service network. This distance is determined by the competition facing the particular service network and by the risks facing the lessee. The greater the competition or risks, the greater the distance $\mathrm{A}^{\prime} \mathrm{D}$.

The vertical line CG is the willingness-to-supply constraint; the vertical line $\mathrm{DH}$ is the willingness-to-lease constraint. The area between these lines illustrates the potential for providing and leasing industrial plants and services. A ceiling may be determined by capital constraints. These constraints are twofold: (1) the maximum number of factories which can be constructed and services which can be provided in one year, and (2) the maximum number for which financing can be 
found. If the production rate constraint is $\mathrm{OE}$ and the finance constraint is $O F$, then the construction rate constraint is the more binding. (In principle, either constraint can be binding; relatively elastic sources of financing are assumed here.) The horizontal line EGH is the capital constraint. Thus, the box CGHD shows the three binding constraints on the service network: costs of business, minimum acceptable benefits from the service network, and financing capital available. The area bounded by CGHD depicts the viability of the service network as a growing concern.

Various conditions may alter these constraints. Anything which tends to move the willingness-to-supply constraint (CG line) to the left, or the willingness-to-lease constraint (DH line) to the right, or the capital constraint (GH line) up increases the long-run viability of the service network. Anything which tends to create opposite movements decreases the long-run viability of the service network.

Consider first the CG line. Higher business taxes shift the CG line to the right, reducing the size of the viability area. An inefficient supplier of services with cost overruns also shifts the CG line to the right. If taxes are excessive or if management is inefficient, these constraints can get out of control and the service network can fail.

Consider now the $\mathrm{DH}$ line. If alternatives to the service network become increasingly attractive, the DH line is likely to move to the left. If the quality and variety of the network's services improve, the value added by the services increases and the $\mathrm{A}^{\prime}$ point moves to the right, pulling the $\mathrm{DH}$ line to the right. This pair of circumstances may be seen as a sequence: whenever the service network is faced with growing competition, it must innovate.

Finally, some cases involving the ceiling may be noted. If the financial constraint is binding, an increase in the availability of financing shifts the ceiling up. On the other hand, if the construction rate constraint is binding, unanticipated delays in construction shift the ceiling down.

Graph 1 may be completed to show the equilibrium ${ }^{70}$ of the service network over one year. In graph 2 the viability area is highlighted. A willingness-to-lease curve begins at $\mathrm{D}$ and is upward-sloping; the larger the benefits to lessees (measured from the right), the greater the number of factories which are filled. The willingness-to-lease curve hits the ceiling at $I$.

The willingness-to-supply curve begins at $\mathrm{C}$ and is probably an upward-sloping step function. Since industrial plants are probably built in groups, each step contains a standard number of factories. It is assumed that the willingness-to-supply curve hits the ceiling at $\mathrm{J}$. The equilibrium point is marked at $\mathrm{K}$, so that the number of plants built and leased is the distance KL. In terms of steps, this is four groups of industrial plants. The service network's profit per lessee is CL. The benefits accruing to each lessee are LA'.

The steepness or elasticity of these curves depends upon expectations and competition. Thus, if the degree of competition facing the service network in acquiring lessees is underestimated, $\mathrm{L}$ will be farther to the left because the willingness-tolease curve will be more elastic. The elasticity of the willingness-to-supply curve 


\section{GRAPH 2}

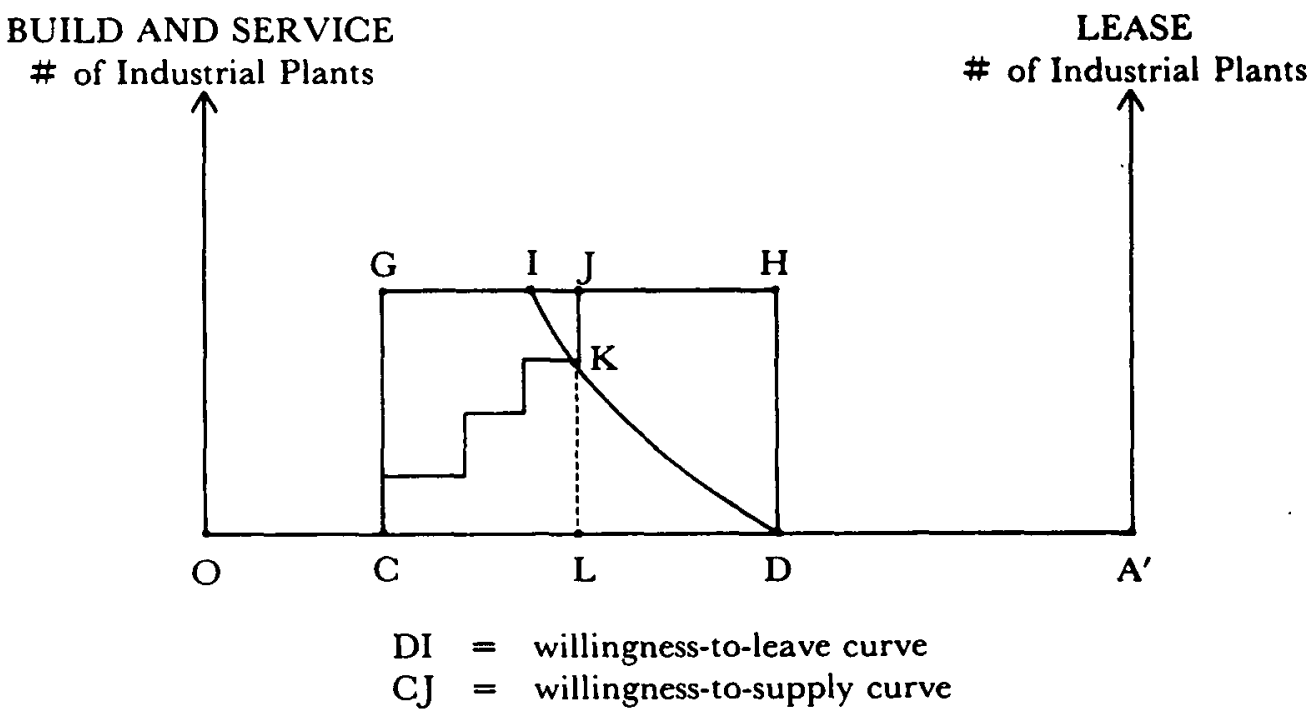

will be sensitive to the degree of competition in the bidding process involving construction firms and service subcontractors. The greater the amount of construction competition, the farther right $\mathrm{L}$ will be because the willingness-to-supply curve will be more elastic.

In principle, three kinds of disequilibrium may also be present. There may be an excess-demand disequilibrium if the ceiling is too low. This is likely to occur in the early, learning stages of the service network. There may also be an excessdemand disequilibrium in the absence of a low ceiling. The service network could, as a matter of risk-averting strategy, wait-list potential lessees and build industrial plants only when a profitable number have been wait-listed. In principle, there may be an excess supply, but if a wait-listing procedure were followed, an excess supply would be likely to occur only during an international trade crisis. That, indeed, would be the sort of disequilibrium over which no control may be exerted.

This economic analysis is a simple reflection of the potential for establishing new labor-intensive operations in labor-surplus countries. The key to the transfer of capital is the provision of services which can overcome the current barriers to foreign investment. With the help of well-coordinated service corporations, a new international industry may emerge as a bridge between North and South. Although this paper emphasizes the relationship between the United States and Mexico, the same concepts may be applied to any situation where neighboring rich and poor countries encounter immigration and foreign investment problems. ${ }^{71}$

70. To the extent that motivation is a relevant factor, X-Efficiency Theory should be kept in mind. See H. Leibenstein, General X-Erficiency Theory and Economic Development (1978).

71. Germany would find such a service organization efficacious in Turkey; France would find it useful in Morocco. 
VI.

\section{Summary and POlicy IMPlications}

This paper has sketched a picture of the contemporary problem of demographic growth as a consequence of economic underdevelopment. This problem is the real cause of today's migration to the United States. Accordingly, U.S. immigration policy should be concerned with the movement of capital as well as people. It behooves us to confront causes, not symptoms. Consider:

(1) Human population is now growing more rapidly than at any previous time in world history. World population will increase by nearly 3,000,000,000 in the last quarter of this century, the growth being largely confined to the less developed regions of the world.

(2) Demographic growth is always a temporary phenomenon; the increase must eventually be checked.

(3) Demographic growth is the result of, and contributes to, economic underdevelopment. Population will continue to grow in the underdeveloped areas of the world until it is checked by economic development, coerced fertility limitations, war, or Malthusian consequences.

(4) The United States is presently receiving more immigrants than ever before in its history. These new immigrants are arriving principally from Latin America, Asia, and the Caribbean-the less developed regions of the world. Demographic increase is the impetus behind today's immigration.

(5) If labor is mobile, it will migrate from areas of relative surplus to areas of relative shortage; that is, it will move from areas which are economically underdeveloped to areas which are economically developed in the process of seeking higher wages.

(6) The United States will increasingly be the recipient of the world's growing poor population unless it effectively restricts the mobility of labor. The magnitude of world population growth already vastly exceeds the absorptive capacity of this country; the number of immigrants we are absorbing already exceeds the optimum number for our own economic prosperity.

(7) Capital, like labor, will migrate from areas of relative surplus to areas of relative shortage if it is permitted to do so. Thus, capital will move from areas which are economically developed to areas which are economically underdeveloped, seeking a high rate of return.

(8) The economic and social effects of capital and labor mobility are asymmetrical. From the perspective of both developed and developing countries, capital mobility is preferred to labor mobility (although developing countries would prefer the mobility of both factors). Private foreign investment may produce dramatic economic benefits for both donor and recipient countries; the same is not true for labor migration.

The facts as summarized suggest the following policy implications:

-The United States should foster capital mobility while restricting labor mobility as a comprehensive immigration policy. Such a policy would treat the disease rather than the symptoms. The resources of this country are finite, and we 
should concentrate our efforts to deal with economic underdevelopment in a fashion which will produce mutual, synergistic benefits.

- The greatest hope for accelerating the flow of capital to developing countries is through the creation of new international divisions of labor, supplying appropriate services to labor-intensive businesses which could benefit from low-cost labor. Without such market mobilization, the opportunity cost of relocating manufacturing operations in developing countries will continue to be unacceptably high, and few developing countries will be able to absorb their growing adult populations into productive employment.

By pursuing a highly restrictive immigration policy while promoting overseas private investment, the U.S. Government not only acts in the national interest, but also remains most responsive to the core problem-economic underdevelopment. Far from abandoning the poor, the United States would be lending the assistance most needed for developing countries to avoid a Malthusian catastrophe. Such assistance would be in our country's long-term best interest as well as theirs, for it is undeniably America's wish to see more of the globe developed and prosperous.

In the meantime, the law according to Emma Lazarus must be revised. Securing our borders is more than an act of self-interest; it is an act of self-preservation. Population growth will be checked in one way or another in the next decades, and when that happens the world will be very different from what it is today. We can reopen the golden door once world population has stabilized, but not before. If we open the door to a world which is economically developed, such prosperity will be partly of our own making. 
